\begin{tabular}{|c|c|c|}
\hline & International Journal of Engineering \& Technology, 7 (4) (2018) 4754-4756 & \\
\hline & International Journal of Engineering \& Technology & \\
\hline SPPC & $\begin{array}{c}\text { Website: } \text { www.sciencepubco.com/index.php/IJET } \\
\text { doi: } 10.14419 \text { /ijet. v7i4.19617 } \\
\text { Research paper }\end{array}$ & Le. \\
\hline
\end{tabular}

\title{
Mechanical characterization of composites polyester moulding reinforced waste metal lathes with standard ASTM D 638-Ill modification
}

\author{
Iswandi Idris ${ }^{1}$ *, Ruri Aditya Sari ${ }^{1}$, Hendriko ${ }^{2}$, Hendri Novia Syamsir ${ }^{3}$ \\ ${ }^{1}$ Industrial Engineering, Politeknik LP3I Medan, Medan, Indonesia \\ ${ }^{2}$ Mechatronic Engineering, Politeknik Caltex Riau \\ ${ }^{3}$ Electrical Engineering, Politeknik Caltex Riau, Rumbai, Indonesia \\ *Corresponding author E-mail: iswandi.idris@plm.ac.id
}

\begin{abstract}
Scope and Objectives of this research are: To improve the mechanical characteristics of polyester composite fabricated waste metal lathe and Styrofoam through tensile test, compression test, impact test, obtain a new note for developing new composite materials by use waste metal lathe and plastic waste Styrofoam in order not to waste. from the test results obtained tensile strength $0.66 \mathrm{~kg} \mathrm{f} / \mathrm{mm} 2$, greatest moment 5,490 kg f.m, greatest stress $1.93 \mathrm{~kg} \mathrm{f} / \mathrm{mm} 2$, strain $0.17093 \mathrm{~m} / \mathrm{m}$ and bending angle 167.64 . The breakpoints of the composite specimen in which the waste lathe located is at 0.65 , the elastic behaviour seen from the number 0 to the 1.06 proportional limit, then at the voltage level 1.1 of the plastic behaviour and the 1.633 level has undergone plastic deformation until the breakpoints.

The charphy impact implies $110(\mathrm{~J} / \mathrm{mm} 2)$. From the experimental results showed that the composite fabric waste has good mechanical properties.
\end{abstract}

Keywords: Polyester Reinforce; Metal Waste; ASTM D 638-III; Mechanical Test

\section{Introduction}

Review of properties of composite materials including polymer matrix composites, metal matrix composites [1] already research, tensile strength of composite cane fiber [2]. The natural fibers have been abundantly available in the world[3] The mechanical properties of the green composites were evaluated as a function of fiber content [4]. The damage of composite structures caused by impact events is one of the most critical behaviours that inhibits more widespread application of composite material [5]. The formation of composite materials represents an efficient route to improve the performances of polymers and expand their application scopes [6]. Classification and properties of composite materials including polymer matrix composites, metal matrix composites, ceramic matrix composites and carbon-carbon composites [7]. Research of fatigue of composite materials, particularly fibre-reinforced plastics, used in aerospace and other industries [8]. The swelling of the composite by PEG and especially its ability to coordinate protons seems to be essential for the catalytic activity of the composite [9]. research also arrived at Two-dimensional (2D) layered nanostructure composites [10]. plasmonics: metal-metal, metal-dielectric, and metalsemiconductor composite nanostructures [11]. knowledge on efficiency and robustness of composite likelihood Scope and Objectives of the research are: To improve the mechanical characteristics of polyester composites with metal waste lathe inference [12] dental composite materials [13]. Micromechanics of Composite Materials [14]. carbon nanotube and graphene have been mostly studied as a second phase to produce high performance polymer composites [6]. kenaf-glass (KG) fibres reinforced unsaturated polyester hybrid composite on a source of green composite using sheet moulding compound process [15]. the composite materials recycling will be available and more easily recyclable composite materials will be developed in the future [16]. the biaxial response of graphite/epoxy composites [17]. the intrinsic relationship between the catalytic properties and the physical and chemical effects in the composite materials [18].

A composite damage model based on continuum damage mechanics (CDMs) is proposed for the progressive damage analysis of a composite structure [19]. the mechanical properties of the composites are significantly influenced by interfacial interactions between nanotubes and polymer matrices [20]. The mechanical properties of the carbon/epoxy composites, in the bulk material, were considerably higher than those of the glass/epoxy [21]. non-destructive testing (NDT) methods for the evaluation of composites [22]. the pineapple leaf fibers (PALF) have a potential for composite reinforcement [23].

Scope and Objectives of the research are: To improve the mechanical characteristics of polyester composites with metal waste lathe[24] through tensile test[25], compression test, impact test[5]. This research is develop earlier composite research. Expect defective specimens or to well specimens during the course of the study, the specimens plus quantities with varying specimens of mixed composite percentage mixtures to the metal waste of lathe and Styrofoam this obtaining the right composition when mechanical tests performed to produce a composite material new ones that have mechanical characteristics. Although develop composite metal waste lathe manufacturers have been widely used and known by the name of the Orgonite, but there is no scientifically acceptable research for this product. A critical and 
conceptual approach to composite metal waste lathe and Styrofoam recommended as a product that detected experimental mechanical ability by using standardized moulding tensile test (ASTM D 638III)[26] while still exploring composite research articles.

\section{Methodology}

The materials used polyester resin, hardened matrix, metal lathe waste [27], Styrofoam, catalyst (hardened), oil. The research conducted by resin comparison variable with lathe waste, and Styrofoam, lathe waste length and compressed strength on compressing process. Composite making with the best composition. Then, the data processing able to explain how the effect of variable variables on the mechanical properties of composite material produced. From the research, expected to reach the way of making the right composite material, the material ratio, the length of fibre and the compressed strength to get good quality composite material.

To reach quality the composite material, mechanical test of similar composite materials market. The research done by resin comparison variable with lathe waste and Styrofoam, metal waste length and compressed strength in pressing process. Then, the data done processing to know how variable influence to the mechanical properties of the composite material produced. From the research, expected to know the way of making the right composite material, the material ratio, the fibre length and the compressed strength to get good quality composite material.

Each composite material produced under certain process conditions, each measured using a specified test apparatus, mechanical tests carried out, among others.

a) Compression test (bending test)

b) Tensile test

c) Impact test (impact charphy test)

Phase testing of testing phase with good rules and correct according to standard to get valid test result (Table 1)

Table 1: A Specimen Dimensions for Thickness, $\mathrm{T}, \mathrm{mm}$ [in]

\begin{tabular}{|c|c|c|c|c|}
\hline \multirow{2}{*}{ Dimwnsions (see drawings) } & \multicolumn{2}{|c|}{$7[0.28]$ or under } & \multicolumn{2}{|c|}{ Over 7 to $14 \quad[0.28$ to 0.55$]$, inel } \\
\hline & Type 1 & Type II & Type III & Ty \\
\hline W-Woth of narrow sectioner & $13[0.50]$ & $6[0.25]$ & $19[0.75]$ & \\
\hline$L$-Length of narrow section & $57[2.25\rceil$ & $57[225]$ & $57[2.25]$ & 3: \\
\hline $\begin{array}{l}\text { Wo-Wiah overall, min } \\
\text { wo-Wath overall, min } \\
\text { mo }\end{array}$ & $19[0.75]$ & $19[0.75]$ & $29[1,13]$ & 1 \\
\hline $\begin{array}{l}\text { Wo-Wath overall, } \min ^{\circ} \\
\text { Lo-Length overal, } \min ^{\mathrm{N}}\end{array}$ & $165[6.5]$ & $183[7.2]$ & $246[9.7]$ & 11 \\
\hline $\begin{array}{l}\text { G-Gape length' } \\
G-G a g 0 \text { length' }\end{array}$ & $50[2.00]$ & $50[200]$ & $50[2.0)$ & \\
\hline D-Distance between grips & $115[4.5]$ & $135[5.3]$ & $115[4.5]$ & \\
\hline$R$-Radias of fllet & $76[3.00]$ & $76[300]$ & $76[3.00]$ & 1 \\
\hline RO-Outer radius (Type $\mathrm{M}$ ) & $\ldots$ & $\ldots$ & ... & 2 \\
\hline
\end{tabular}

\section{Results and discussion}

\section{ASTM D638 Type III}

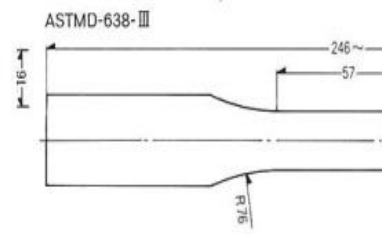

Fig. 1: Dimensional Specimen Testing[26].

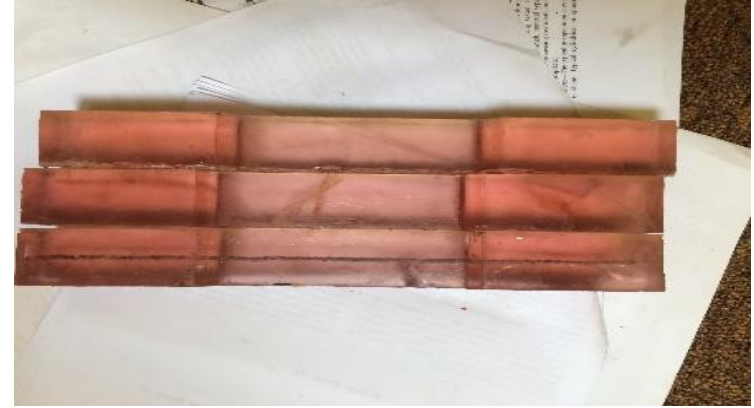

Fig. 3: Specimen Composite Reinforced Waste Lathe.

A Thickness, T, shall be $3.260 .4 \mathrm{~mm}$ [0.13 60.02 in.] For all types of molded specimens, and for other Types I and II specimens where possible. If specimens are machined from sheets or plates, thickness, T, may be the thickness of the specimen type. For sheets of nominal thickness greater than $14 \mathrm{~mm}$ [0.55 in.] The specimens shall be machined to $1460.4 \mathrm{~mm}$ [0.55 60.02 in.] In thickness, for use with the Type III. specimen. For sheets of nominal thickness between 14 and $51 \mathrm{~mm}$ [0.55 and 2 in.] [26].

From the above reference then the specimen is modified with a thickness of $30 \mathrm{~mm}$.

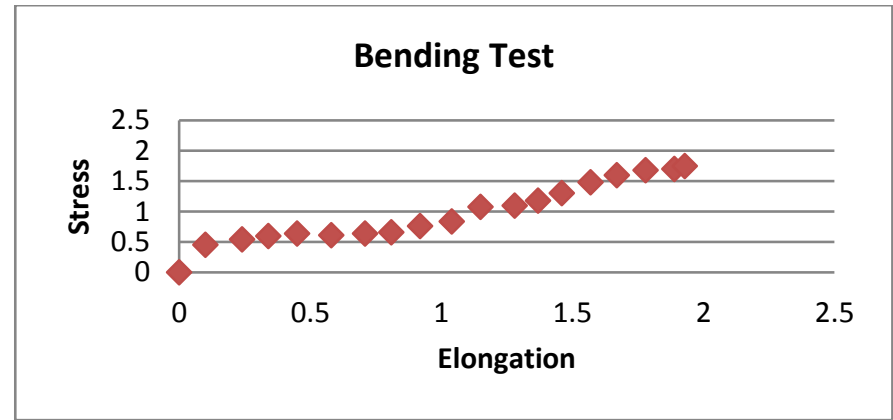

Fig. 4: Bending Test Results of 30 Specimens.

From the test results obtained tensile strength results $0.66 \mathrm{~kg} \mathrm{f} /$ $\mathrm{mm} \mathrm{2,} \mathrm{greatest} \mathrm{moment} \mathrm{5,490} \mathrm{kg} \mathrm{f.m,} \mathrm{greatest} \mathrm{stress} 1.93 \mathrm{~kg} \mathrm{f} /$ $\mathrm{mm} 2$, strain $0.17093 \mathrm{~m} / \mathrm{m}$ and bending angle 167.6.

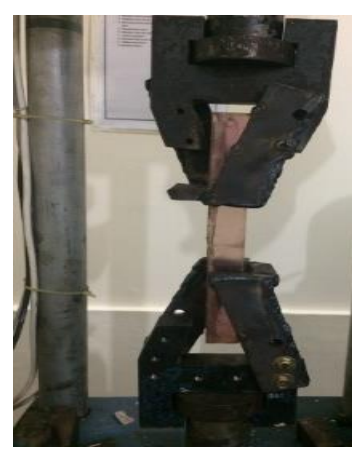

Fig. 5: Cross Section of Tensile Tes.

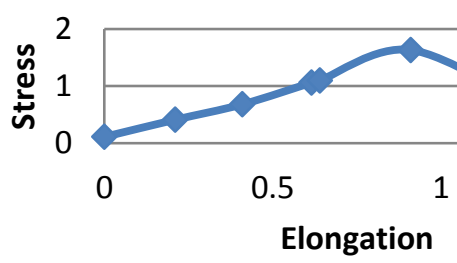

Fig. 6: Tensile Test Results of 30 Specimens.

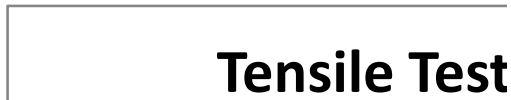

The breakpoints of the composite specimen in which the waste lathe located is at 0.65 , the elastic behaviour seen from the number 0 to the 1.06 proportional limit, then at the voltage level 1.1 of the plastic behaviour and the 1.633 level has undergone plastic deformation until the breakpoints.
Fig. 2: Specimen ASTM D638 $03[26]$. 


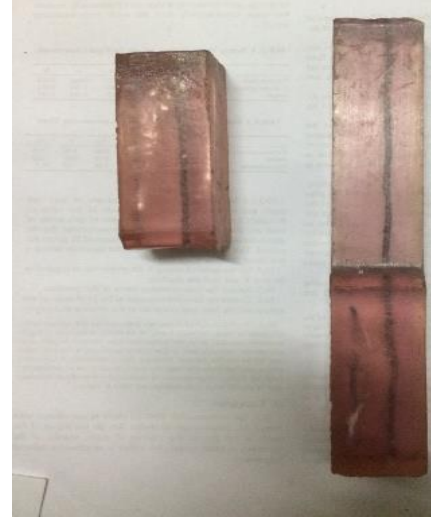

Fig. 7: The Result of A Composite Tensile Strength Test with A Specimen of Waste Lathe.

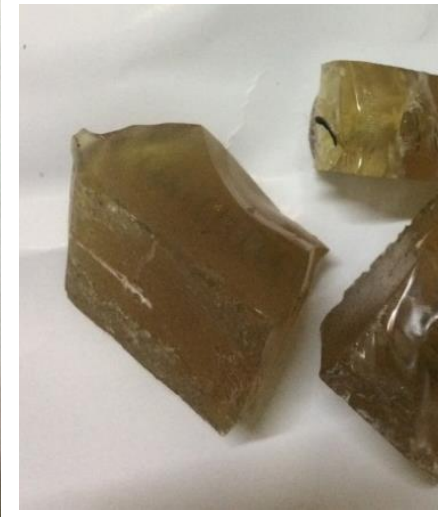

Fig. 8: Broken One of the Specimens after the Charphy Impact.
The composite impact with charphy of the lathe waste show $110(\mathrm{~J}$ $/ \mathrm{mm} \mathrm{2}$ ) which is the result of the absorbent energy ( $\mathrm{J}$ ) compared to the cross-sectional area ( $\mathrm{mm} \mathrm{2)}$.

\section{Conclusion}

In this study, to improve the mechanical characteristics of polyester composite fabricated waste metal lathe through compression test. Through this study, from the test results obtained tensile strength $0.66 \mathrm{~kg} \mathrm{f} / \mathrm{mm} 2$, greatest moment $5,490 \mathrm{~kg}$ f.m, greatest stress $1.93 \mathrm{~kg} \mathrm{f} / \mathrm{mm} 2$, strain $0.17093 \mathrm{~m} / \mathrm{m}$ and bending angle 167.64, The breakpoints of the composite specimen in which the waste lathe located is at 0.65 . The charpy impact is $110(\mathrm{~J} / \mathrm{mm} \mathrm{2})$.

\section{Acknowledgement}

Acknowledgement given for Direktorat Riset dan Pengabdian Masyarakat, Direktorat Jenderal Penguatan Riset dan Pengembangan (DRPM) KEMENRISTEKDIKTI Republic of Indonesia, because this research carried out by funding from the grant DRPM DIKTI fiscal years 2017 and 2018 for Pekerti research scheme.

\section{References}

[1] D. D. L. Chung, Composite Materials, vol. 22, no. 2. 2010.

[2] P. A. Nugroho, Mustaqim, and Rusnoto, "Analisa Sifat Mekanik Komposit Serat Tebu dengan Matrik Resin Epoxy,” J. Eng. - FT. Univ. Pancasakti Tegal, vol. 4, no. 1, pp. 56-64, 2012.

[3] T. Sathishkumar, P. Navaneethakrishnan, S. Shankar, R. Rajasekar, and N. Rajini, "Characterization of natural fiber and composites - A review,” J. Reinf. Plast. Compos., vol. 32, no. 19, pp. 1457-1476, 2013. https://doi.org/10.1177/0731684413495322.

[4] H. Takagi and T. Fujii, "Mechanical Characterization of Bamboo Fiber-Reinforced Green Composites," Key Eng. Mater., vol. $577-$ 578, pp. 81-84, https://doi.org/10.4028/www.scientific.net/KEM.577-578.81.

[5] N. Razali, M. T. H. Sultan, F. Mustapha, N. Yidris, and M. R Ishak, "Impact Damage on Composite Structures - A Review," Int J. Eng. Sci., pp. 2319-1813, 2014.

[6] X. Sun, H. Sun, H. Li, and H. Peng, "Developing polyme composite materials: Carbon nanotubes or graphene?," Advanced Materials, vol. 25, no. 37. pp. 5153-5176, 2013. https://doi.org/10.1002/adma.201301926.

[7] K. K. Chawla, Composite Materials. 2012.

[8] C. Bathias, "Fatigue of composite materials," in Fatigue of Materials and Structures: Application to Damage and Design, 2013, pp. 179-204.

[9] B. Winther-Jensen, K. Fraser, C. Ong, M. Forsyth, and D. R. MacFarlane, "Conducting polymer composite materials for hydrogen generation," Adv. Mater., vol. 22, no. 15, pp. 1727-1730, 2010. https://doi.org/10.1002/adma.200902934.
[10] J. Low, S. Cao, J. Yu, and S. Wageh, "Two-dimensional layered composite photocatalysts," Chem. Commun., vol. 50, no. 74, p. 10768, 2014. https://doi.org/10.1039/C4CC02553A

[11] H. Wei and H. Xu, "Plasmonics in composite nanostructures," Materials Today, vol. 17, no. 8. pp. 372-380, 2014. https://doi.org/10.1016/j.mattod.2014.05.012.

[12] C. Varin, N. Reid, and D. Firth, "An overview of composite likelihood methods," Stat. Sin., vol. 21, pp. 5--42, 2011.

[13] J. L. Ferracane, "Resin composite-State of the art," Dent. Mater., vol. 27, no. 1, pp. 29-38, 2011 https://doi.org/10.1016/j.dental.2010.10.020.

[14] J. Aboudi, S. Arnold, and B. Bednarcyk, Micromechanics of Composite Materials. 2013

[15] A. Atiqah, M. A. Maleque, M. Jawaid, and M. Iqbal, "Development of kenaf-glass reinforced unsaturated polyester hybrid composite for structural applications," Compos. Part B Eng.,

[16] Y. Yang, R. Boom, B. Irion, D. J. van Heerden, P. Kuiper, and H. de Wit, "Recycling of composite materials," Chem. Eng. Process. Process Intensif., vol. 51, pp. 53-68, 2012. https://doi.org/10.1016/j.cep.2011.09.007.

[17] K. K. Chawla, Composite materials. 2013.

[18] J. Yang and H. Liu, Metal-based composite nanomaterials. 2015.

[19] E.-H. Kim, M.-S. Rim, I. Lee, and T.-K. Hwang, "Composite damage model based on continuum damage mechanics and low velocity impact analysis of composite plates," Compos. Struct., vol. 95, pp. 123-134, 2013 https://doi.org/10.1016/j.compstruct.2012.07.002

[20] B. Arash, Q. Wang, and V. K. Varadan, "Mechanical properties of carbon nanotube/polymer composites.," Sci. Rep., vol. 4, p.6479, 2014. https://doi.org/10.1038/srep06479.

[21] N. Guermazi, N. Haddar, K. Elleuch, and H. F. Ayedi, "Investigations on the fabrication and the characterization of glass/epoxy, carbon/epoxy and hybrid composites used in the reinforcement and the repair of aeronautic structures," Mater. Des. vol. 56, pp. 714-724, 2014 https://doi.org/10.1016/j.matdes.2013.11.043.

[22] S. Gholizadeh, "A review of non-destructive testing methods of composite materials," Procedia Struct. Integr., vol. 1, pp. 50-57, 2016. https://doi.org/10.1016/j.prostr.2016.02.008.

[23] G. Oliveira, M. Carolina, A. Teles, F. Perissé, D. Lopes, C. Maurício, F. Vieira, F. Muylaert, M. De Almeida, and S. Neves, "Tensile strength of polyester composites reinforced with PALF," J. Mater. Res. Technol., vol. 298, no. x x, pp. 6-10, 2017.

[24] A. Lisdiana, A. D. Rosalia, N. J. Asrilya, and R. N. Latifah, "Utilization of Metal Lathe Waste as Material for the Absorption of Electromagnetic Radiation Based Orgonite," Int'l J. Adv. Agric. Environ. Engg., vol. 1, no. 1, pp. 57-60, 2014.

[25] M. Ravandi, W. S. Teo, L. Q. N. Tran, M. S. Yong, and T. E. Tay, "Mode $\mathrm{i}$ interlaminar fracture toughness of natural fiber stitched flax/epoxy composite laminates-Experimental and numerical.

[26] ASTM International, "Standard Test Method for Tensile Properties of Plastics 1," ASTM Int., no. January, pp. 1-16, 2003.

[27] H. N. S. Iswandi Idris, Ruri Aditya Sari, Hendriko, "Manufacturing Process For Composite Reinforce Waste Lathe With Standard ASTM D 638-III," JOJAPS, vol. 10, no. 53, pp. 3-8, 2017. 